\title{
Genetic Variability, Heritability and Genetic Advance of Groundnut (Arachis hypogaea L.) Genotypes at Assosa and Kamashi, Western Ethiopia
}

\author{
Aliyi Robsa Shuro \\ Assosa Agricultural Research Center (AsARC), Ethiopian Institute of Agricultural Research (EIAR), Addis Ababa, Ethiopia \\ Email address: \\ aliyirobsa@gmail.com \\ To cite this article: \\ Aliyi Robsa Shuro. Genetic Variability, Heritability and Genetic Advance of Groundnut (Arachis hypogaea L.) Genotypes at Assosa and \\ Kamashi, Western Ethiopia. Agriculture, Forestry and Fisheries. Vol. 10, No. 5, 2021, pp. 189-195. doi: 10.11648/j.aff.20211005.14
}

Received: September 21, 2021; Accepted: October 8, 2021; Published: October 28, 2021

\begin{abstract}
The lowland areas of Ethiopia have significant potential for increased oil crop production including groundnut. In Benishangul Gumuz Region, groundnut is cultivated in various zones and woredas under rain fed condition. However, due to insufficient improved groundnut varieties found in the region the productivity was low. Testing genotypes for the presence of variations and generation of genetic information is the first step in plant breeding to develop varieties for the targeted area of production. Keeping these in account the current study was conducted with the objectives of determining the genetic variability and trait association and their direct and indirect effects on yield and yield related traits of groundnut genotypes at Assosa and Kamashi zones, Western Ethiopia. Twenty five groundnut genotypes were evaluated in 5 x 5 triple lattice designs. Data were recorded for 16 traits and subjected to ANOVA using SAS software. Further genetic analyses were conducted as per the formula suggested by biometricians. Analyses of variance showed mean square due to genotypes were highly significant $(\mathrm{p} \leq 0.01)$ for all traits studied except seeds $\operatorname{pod}^{-1}$ at both locations. High heritability value coupled with high genetic advance as percent of mean was observed for primary branches plant ${ }^{-1}, 100$-seed weight, dry pod yield and grain yield hectare ${ }^{-1}$ at Assosa and Kamashi. Therefore, the current study revealed the presence of considerable variability for most of the traits studied and differences in the performance of the genotypes as there were significant differences among genotypes. Emphasis should be given for dry pod yield hectare ${ }^{-1}$, primary branches plant ${ }^{-1}$, pods plant ${ }^{-1}$ and 100 -seed weight to enhance grain yield production.
\end{abstract}

Keywords: Heritability, Genetic Advance, Variation

\section{Introduction}

The lowland areas of Ethiopia have considerable potential for increased oil crop production including groundnut. The estimated annual groundnut production in Ethiopia was about $103,062.38$ tons from $64,649.34$ hectares of production area. The average national yield was about 1.6 tons per hectare [7]. In Benishangul Gumuz Region, groundnut is cultivated in various zones, woredas and pocket areas of the region under rainfed condition. The annual production of groundnut in Metekel, Assosa and Kamahi zones of the region were 24,467.045, $1,019.184$ and 199.728 tons with productivity of $1.7,1.4$ and 1.4 tons per hectare respectively in the previous cropping season [7]. This low productivity of the crop was attached to insufficient improved varieties released in the region.

The aim of groundnut breeding programs across the world is to develop new varieties that meet the requirements of growers, processors, and consumers. Estimate of the extent and pattern of genetic variability existing in the available genotypes brings about the evaluation of genetic and environmental effects, aiding in selection. Selection of potential genotypes from the existing germplasm, utilizing them in the hybridization programme and isolation of the superior segregants in the segregating population are the usual breeding strategy in highly self-pollinated crops like groundnut. However, genetic improvement of grain yield through phenotypic selection alone is not possible because of polygenic nature and low heritability of the traits. High heritability is also needed to have better opportunity to select directly for the characters of interest. Thus, effectiveness of selection is dependent upon the nature, extent and magnitude of genetic variability present in the materials and the extent to which it is heritable. Estimate of 
heritability assists breeder to allocate resources necessary to effectively select for desired traits and to achieve maximum genetic gain with little time and resources. The information on heritability alone may not help in identifying characters for enforcing selection; therefore, heritability estimates in conjunction with predicted genetic advance is more reliable [11]. Therefore, in groundnut breeding programs, information on the extent and pattern of genetic variability present in a population and the relationship between various characters and their contribution to yield is paramount to increase groundnut production in the region as well in a country. However, no work has been conducted at considered areas describing the nature and extent of genetic variability and trait associations.
Owing this, the Objectives of this study were to estimate the magnitude of genetic variability for grain yield, yield related traits and oil content in groundnut genotypes.

\section{Materials and Methods}

\subsection{Description of the Experimental Sites}

The experiment was conducted at Assosa on station and Kamashi sub center of Assosa Agricultural Research Center (AsARC) experimental field, in Benishangul-Gumuz regional state (BGRS), Western Ethiopia during 2016 main cropping season.

Table 1. Description of the experimental sites.

\begin{tabular}{|c|c|c|c|c|c|c|c|}
\hline \multirow{2}{*}{ Study site } & \multicolumn{2}{|c|}{ Geographical position } & \multirow{2}{*}{ Elevation (m.a.s.l.) } & \multicolumn{2}{|c|}{ Annual mean Temp. $\left({ }^{\circ} \mathrm{C}\right)$} & \multirow{2}{*}{ Annual rainfall (mm) } & \multirow{2}{*}{ Soil type } \\
\hline & Latitude & Longitude & & Min. & Max. & & \\
\hline Assosa & $10^{\circ} 02.505^{\prime \prime}$ & $34^{\circ} 34.319^{\prime \prime} \mathrm{E}$ & 1554 & 12.4 & 25.0 & 1056 & Nitosol \\
\hline Kamashi & $09^{\circ} 31.444^{\prime \prime}$ & $035^{\circ} 53.222 " \mathrm{E}$ & 1215 & 17.5 & 29.1 & 1486 & Nitosol \\
\hline
\end{tabular}

\subsection{Experimental Materials and Design}

The experimental materials comprise of 23 advanced groundnut genotypes along with two released groundnut varieties, namely, Maniputer and Roba. The experiment was laid out in a $5 \times 5$ triple lattice design. Each genotype was planted in a plot size of $15 \mathrm{~m}^{2}$ ( $3 \mathrm{~m}$ plot width $\mathrm{x} 5 \mathrm{~m}$ row length) and accommodated five rows at $0.6 \mathrm{~m}$ interval. There was $0.1 \mathrm{~m}$ distance between plants within a row. The spacing between plots and blocks were $0.6 \mathrm{~m}$ and $1 \mathrm{~m}$, respectively. Fertilizer was not applied, but weeding and all other recommended agronomic practice was followed for both locations.

\subsection{Data Collection}

Data were collected on plot basis and plant basis from the central three rows for all parameters. For data recorded on plant basis five plants were randomly taken and tagged from the net harvestable plots and the mean value of these five plants were calculated using Micro soft Excel. Data collected on plant base includes Plant height, Number of primary branches, Number of secondary branches, Pod length, Number of pods per plant, Number of mature pods per plant and Number of seeds per pod and data collected on plot base were Days to flowering, Days to maturity, Dry pod yield $(\mathrm{kg} / \mathrm{ha})$, Grain yield $(\mathrm{kg} / \mathrm{ha})$, Shelling percentage (SH\%), 100-seed weight and Oil content.

\subsection{Data Analysis}

\subsubsection{Analysis of Variance}

All recorded data were subjected to analysis of variance (ANOVA) using proc lattice and proc GLM of SAS software version 9.0. Mean comparison among genotype were carried out using Duncan Multiple Range Test.

\subsubsection{Estimation of Genetic Parameters}

\section{(i). Variance Components}

Component due to phenotypic variance $\left(\sigma^{2} \mathrm{ph}\right)$, genotypic variance $\left(\sigma^{2} g\right)$ and environmental variance $\left(\sigma^{2} \mathrm{e}\right)$ were calculated by adopting the following formulas suggested by researchers [6].

$$
\begin{gathered}
\text { Environmental variance }\left(\sigma^{2} \mathrm{e}\right)=\text { MSe (error mean square) } \\
\text { Genotypic variance }\left(\sigma^{2} \mathrm{~g}\right)=\frac{\text { Msg-Mse }}{\mathrm{r}} \\
\text { Phenotypic variance }\left(\sigma^{2} \mathrm{p}\right)=\sigma^{2} \mathrm{~g}+\sigma^{2} \mathrm{e}
\end{gathered}
$$

Where: $-\mathrm{MSg}=$ Mean squares due to genotypes, $\mathrm{MSe}=$ mean square due to error and $\mathrm{r}=$ Number of replications.

The Phenotypic coefficient of variation (PCV) and genotypic coefficient of variation (GCV) were estimated according to the method suggested by researchers [6]. as follows: -

$$
\begin{aligned}
& \text { Phenotypic coefficient of variation }(\mathrm{PCV})=\frac{\sqrt{\text { phenotypic variance }}}{\text { Mean value of the trait }} \mathrm{X} 100 \\
& \text { Genotypic coefficient of variation }(\mathrm{GCV})=\frac{\sqrt{\text { Genotypic variance }}}{\text { Mean value of the trait }} \mathrm{X} 100
\end{aligned}
$$

\section{(ii). Heritability in Broad Sense}

Heritability in broad sense was calculated for each trait by using the formula [1]. 


$$
h^{2} \mathrm{~b}(\%)=\frac{\sigma^{2} \mathrm{~g}}{\sigma^{2} \mathrm{ph}} \times 100
$$

Where: $-h^{2} b=$ Heritability in broad sense,$\sigma^{2} \mathrm{~g}=$ Genotypic variance, $\sigma^{2} \mathrm{p}=$ Phenotypic variance.

\section{(iii). Estimation of Expected Genetic Advance}

The expected genetics advance (EGA) under selection, assuming the selection intensity of $5 \%$ was calculated as proposed by [11] as follows.

$$
\mathrm{EGA}=\mathrm{K} \cdot \sqrt{\sigma^{2} \mathrm{ph}} \cdot \frac{\sigma^{2} \mathrm{~g}}{\sigma^{2} \mathrm{p}}=\mathrm{k} * \sigma_{\mathrm{ph}} * h^{2} \mathrm{~b}
$$

Where $\mathrm{EGA}=$ expected genetic advance, $\mathrm{K}=$ the selection differential $\left(\mathrm{K}=2.056\right.$ at $5 \%$ selection intensity), $\sigma_{\mathrm{ph}}$ is the phenotypic standard deviation and $\mathrm{h}_{\mathrm{b}}{ }^{2}$ is heritability in broad sense.

Genetic advance as percent of mean was calculated to compare the extent of predicted advances of different traits under selection, using the formula suggested by [9] as follows.

$$
\mathrm{GAM}=\frac{\mathrm{EGA}}{\mathrm{X}} \mathrm{X} 100
$$

GAM = Genetic advance as percent of mean, EGA = Genetic advance under selection and $\mathrm{X}=$ Mean value.

\begin{tabular}{|c|c|c|c|c|c|c|c|c|c|}
\hline \multirow{3}{*}{ Traits } & \multicolumn{7}{|l|}{ Mean squares } & \multirow{3}{*}{$\begin{array}{l}\text { RE to } \\
\text { RCBD\% }\end{array}$} & \multirow{3}{*}{ CV (\%) } \\
\hline & \multirow[b]{2}{*}{$\begin{array}{l}\text { Replications } \\
(\mathrm{Df}=2)\end{array}$} & \multicolumn{2}{|l|}{ Treatment } & \multirow[b]{2}{*}{$\begin{array}{l}\text { Block (Rep.) } \\
\text { (Adj.) (Df=12) }\end{array}$} & \multicolumn{2}{|l|}{ Error } & \multirow{2}{*}{$\begin{array}{l}\text { Total } \\
(\mathrm{Df}=74)\end{array}$} & & \\
\hline & & $\begin{array}{l}\text { Unadjusted } \\
(\mathrm{Df}=\mathbf{2 4})\end{array}$ & $\begin{array}{l}\text { Adjusted } \\
(\mathrm{Df}=\mathbf{2 4})\end{array}$ & & $\begin{array}{l}\text { RCB } \\
(\mathrm{Df}=48)\end{array}$ & $\begin{array}{l}\text { Intra-block } \\
(\mathrm{Df}=36)\end{array}$ & & & \\
\hline DM (no) & 79.69 & 142.05 & $96.81^{* *}$ & 47.12 & 25.19 & 17.88 & 64.57 & 121.95 & 2.95 \\
\hline $\mathrm{PH}(\mathrm{cm})$ & 3.17 & 60.42 & $45.16^{* *}$ & 15.06 & 7.75 & 5.32 & 24.71 & 125.51 & 7.38 \\
\hline PBPP (no) & 1.77 & 7.04 & $6.03^{* *}$ & 0.79 & 0.84 & 0.85 & 2.88 & 98.07 & 15.28 \\
\hline SBPP (no) & 1.27 & 2.44 & $2.13^{* *}$ & 0.48 & 0.47 & 0.46 & 1.13 & 100.03 & 27.56 \\
\hline TPPP (no) & 29.82 & 46.11 & $30.98^{* *}$ & 12.08 & 10.25 & 9.63 & 22.41 & 101.22 & 24.81 \\
\hline MPPP (no) & 30.10 & 39.79 & $26.71^{* *}$ & 9.77 & 7.83 & 7.18 & 18.80 & 102.25 & 26.40 \\
\hline PL $(\mathrm{cm})$ & 0.20 & 0.22 & $0.16^{* *}$ & 0.08 & 0.04 & 0.03 & 0.10 & 130.41 & 6.81 \\
\hline SPP (no) & 0.001 & 0.01 & $0.005^{\mathrm{ns}}$ & 0.004 & 0.004 & 0.004 & 0.005 & 100.05 & 3.33 \\
\hline $100 \mathrm{SW}(\mathrm{g})$ & 2.40 & 248.28 & $195.42^{* *}$ & 13.42 & 12.13 & 11.70 & 88.45 & 100.46 & 8.73 \\
\hline $\operatorname{SHP}(\%)$ & 4.56 & 38.44 & $32.24^{* *}$ & 5.20 & 8.62 & 9.75 & 18.18 & 88.32 & 4.39 \\
\hline PYLD (kg/ha) & 15782 & 707753 & $446142^{* *}$ & 81045 & 69972 & 66281 & 275355 & 100.97 & 20.81 \\
\hline GYLD (kg/ha) & 12639 & 360877 & $235616^{* *}$ & 37812 & 36536 & 36111 & 141082 & 100.05 & 21.16 \\
\hline Oil content $(\%)$ & 0.72 & 14.96 & $10.84^{* *}$ & 1.76 & 0.84 & 0.53 & 5.41 & 134.69 & 1.62 \\
\hline
\end{tabular}

Table 2. Mean squares from Analysis of Variance (ANOVA) for different sources of variation and the corresponding CV for the 16 traits of 25 groundnut genotypes tested at Asosa.

Where: - Adj. $=$ Adjusted, $\mathrm{CV}=$ coefficient of variation, $\mathrm{Df}=$ degree of freedom, $\mathrm{RE}=$ Relative efficiency, $\mathrm{RCBD}=$ Randomized complete block design, $\mathrm{Rep}=$ Replication.

Table 3. Mean squares from Analysis of Variance (ANOVA) for different sources of variation and the corresponding CV for the 16 traits of 25 groundnut genotypes evaluated at Kamashi.

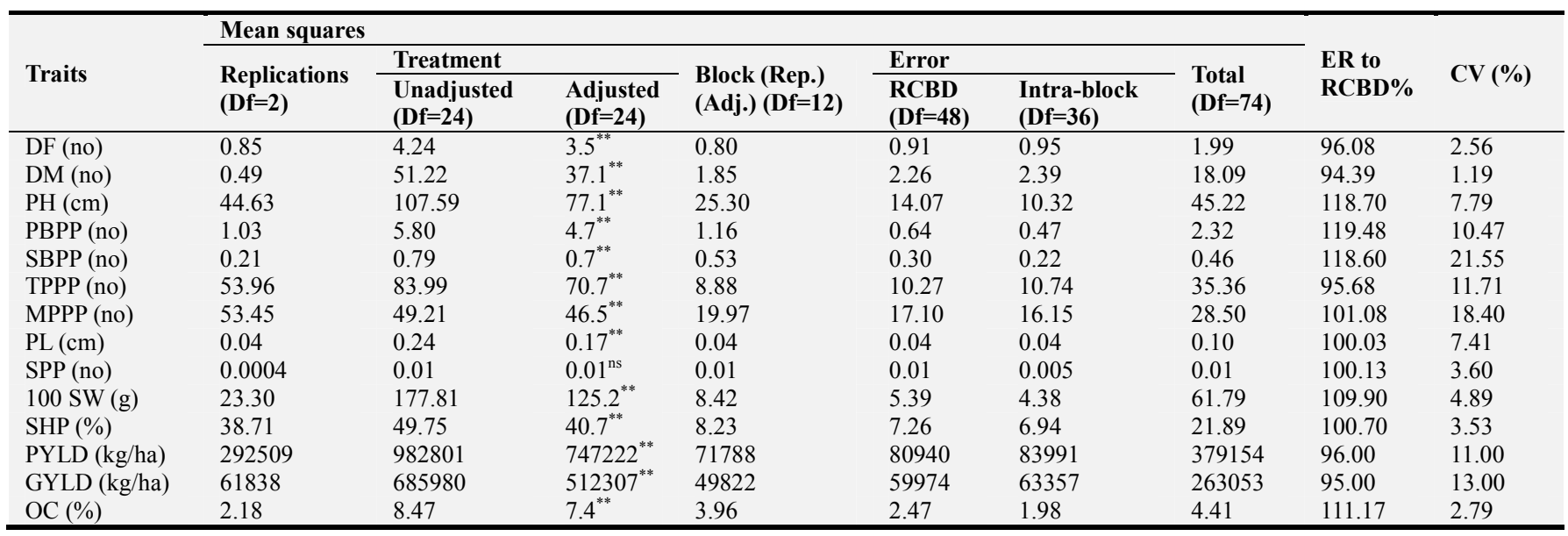

\section{Results and Discussion}

\subsection{Analysis of Variance}

The results showed that mean squares due to genotypes were highly significant $(\mathrm{P} \leq 0.01)$ for all measured traits among studied groundnut genotypes at both locations except for number of seeds per pod which was non-significant $(\mathrm{P}>0.05)$ at both locations. The significant differences obtained in the present experiment indicated the presence of considerable variation in the genetic materials studied. 
The finding in this study was in agreement with report of many researchers. In the study of [10] highly significant differences were observed among fourteen groundnut varieties for all the characters studied viz., grain yield $(\mathrm{kg} / \mathrm{ha})$, pod yield $(\mathrm{kg} / \mathrm{ha})$, harvest index, total pods per plant, mature pods per plant, 100-seed weight $(\mathrm{g}), 100$-pod weight $(\mathrm{g})$, primary branches per plant, secondary branches per plant, days to $50 \%$ flowering, pod filling period, oil content $(\%)$ and grain yield per plant (g). Similar finding also reported by some researchers [5] for days to $50 \%$ flowering, days to $90 \%$ maturity, plant height, 100 -seed weight and grain yield per hectare. The authors also reported non-significant difference for primary branches per plant and seeds per pod in the study.

Bhargavi, Satyanarayana and Narasimha [4] also reported highly significant difference for days to $50 \%$ flowering, days to maturity, number of mature pods per plant, pod yield per hectare, kernel yield per hectare, shelling percentage, 100kernel weight and oil content (\%) in the study of genetic variability, heritability and genetic advance of yield and related traits of groundnut genotypes.

\subsection{Estimates of Variance Components}

\subsubsection{Variance Components}

The results of estimated variance components, phenotypic (PCV) and genotypic coefficient of variation (GCV), broad sense heritability $\left(\mathrm{h}_{\mathrm{b}}{ }^{2}\right)$, expected genetic advance (GA) and genetic advance as percentage of mean (GAM\%) were computed for traits recorded for tested genotypes and presented in tables 4 and 5 for Assosa, Kamashi and combined of the two locations, respectively.

The genotypic variance took relatively much of the total variances for days to $50 \%$ flowering, plant height, primary branches per plant, secondary branches per plant, 100-seed weight, dry pod yield per hectare, grain yield per hectare and oil contents at Assosa. The other traits showed lower share of genetic variance at this location. At Kamashi higher genotypic variance share of the total variance were observed for days to maturity, plant height, primary branches per plant, total pods per plant, 100-seed weight, shelling percentage, dry pod yield and grain yield per hectare. After combined analysis primary branches per plant, total pods per plant, pod length, dry pod yield and grain yield per hectare showed high share of genotypic variance from the total variation. These effects were also detected from high heritability estimates for these traits (Tables 4 and 5). [17] Observed high share of genotypic variance for days to $50 \%$ flowering, plant height, branches per plant, mature pods per plant, shelling percentage and pod yield per hectare. [13] Reported high share of genotypic variance for days to $50 \%$ flowering, plant height, pods per plant, pod yield, shelling percentage and kernel yield and low share of genotypic variance for primary branches per plant and days to maturity. Traits showed lower share of genetic variance in this experiment indicated the greater share of environmental variance in the total variation.

The phenotypic coefficient of variation (PCV) was higher than the genotypic coefficient of variation (GCV) for all traits studied at both locations, indicating that the apparent variation was not only genetic but also was influenced by the growing environment in the expression of the traits. [8] Classify GCV and PCV as high for values greater than $20 \%$, as low for values less than $10 \%$ and as medium for values between 10 and 20\%. Accordingly, high GCV and PCV values were observed for number of primary branches per plant, secondary branches per plant, total pods per plant, number of mature pods per plant, dry pod yield per hectare, grain yield per hectare, early leaf spot and late leaf spot at Assosa. At Kamashi high GCV and PCV values were recorded for early leaf spot and late leaf spot. Hundred seed weight exhibited high PCV value at Assosa, whereas, primary branches per plant, secondary branches per plant, number of mature pods per plant, dry pod yield and grain yield per hectare showed high PCV at Kamashi. The results of high GCV and PCV observed in current experiment exhibited variability for most of the characters considered. These indicated the existence of wider genetic variation in the tested genotypes and implied that there is a good opportunity for the improvement of grain yield in the tested genotypes. Hence, those character can be relied upon and simple selection can be practiced for further improvement. These results confirmed the earlier findings of [17] that Coefficient of variation at phenotypic and genotypic levels was relatively high in kernel yield per hectare, branches per plant, immature and mature pods per plant, 100-kernel weight and plant height.

Balaraju and Kenchanagoudar [3] Also reported high GCV and PCV for number of secondary branches per plant, pods per plant, pod yield per plant, pod yield per hectare, harvest index and percent of disease incidence at harvest. Similar finding of high GCV and PCV also reported by [4] for dry pod yield per plant and dry pod yield per hectare in their study.

Moderate values of GCV and PCV were also noticed in the present study for some traits at both locations. At Assosa moderate GCV and PCV values were observed for plant height. At this location 100-seed weight exhibited moderate GCV, while pod length showed moderate PCV value. At Kamashi plant height, total pods per plant, 100-seed weight and pod length showed moderate GCV and PCV values in this experiment. Number of primary branches and secondary branches per plant, mature pods per plant, dry pod yield and grain yield per hectare showed moderate PCV values at Kamashi location.

Low GCV and PCV were observed for days to $50 \%$ flowering, days to maturity, shelling percentage and oil content at both locations. Pod length exhibited low GCV value at both Assosa and Kamashi. Low PCV and GCV obtained in this experiment indicated the low prevalence of additive gene actions in the expression of these traits and also the difficulty of improving them through simple selection. Such low GCV and PCV for the above traits have been also reported earlier by [3] for shelling percentage, oil content, days to $50 \%$ flowering and days to maturity in their study. [16] Has been also reported low GCV for shelling percentage and days to flowering. 
Table 4. Estimates of variance components, phenotypic (PCV) and genotypic $(G C V)$ coefficient of variability, broad sense heritability $\left(h^{2}{ }_{b}\right)$, expected genetic advance (EGA) and genetic advance as percentage of mean (GAM\%) for 16 traits of groundnut genotypes tested at Assosa.

\begin{tabular}{|c|c|c|c|c|c|c|c|c|c|c|c|c|}
\hline Traits & Mean & SE & $\begin{array}{l}\text { Range } \\
\text { Min. }\end{array}$ & Max. & $\sigma_{\text {ph }}^{2}$ & $\sigma_{\mathrm{g}}^{2}$ & $\sigma_{\mathrm{e}}^{2}$ & PCV & GCV & $\mathbf{h}_{\mathrm{b}}^{2}$ & $\begin{array}{l}\text { EGA } \\
k=5 \%\end{array}$ & $\begin{array}{l}\text { GAM } \\
\text { K=5\% }\end{array}$ \\
\hline Days to $50 \%$ flowering (days) & 48.43 & 1.64 & 44.33 & 54.67 & 12.41 & 8.36 & 4.05 & 7.27 & 5.97 & 67.40 & 4.88 & 10.08 \\
\hline Days to maturity (days) & 143.3 & 3.71 & 132.7 & 155.3 & 49.06 & 23.87 & 25.19 & 4.89 & 3.41 & 48.65 & 7.01 & 4.89 \\
\hline Plant height $(\mathrm{cm})$ & 31.27 & 2.03 & 22.07 & 40.73 & 20.22 & 12.47 & 7.75 & 14.38 & 11.29 & 61.65 & 5.70 & 18.23 \\
\hline Primary branches per plant (no) & 6.05 & 0.75 & 4.47 & 9.93 & 2.57 & 1.73 & 0.84 & 26.50 & 21.76 & 67.41 & 2.22 & 36.73 \\
\hline Secondary branches per plant (no) & 2.46 & 0.56 & 1.33 & 4.87 & 1.02 & 0.55 & 0.47 & 40.98 & 30.21 & 54.34 & 1.13 & 45.78 \\
\hline Total Pods per plant (no) & 12.51 & 2.60 & 7.33 & 21.40 & 17.16 & 6.91 & 10.25 & 33.10 & 21.01 & 40.28 & 3.43 & 27.41 \\
\hline Mature pods per plant (no) & 10.15 & 2.26 & 5.20 & 17.93 & 14.12 & 6.30 & 7.83 & 37.03 & 24.73 & 44.59 & 3.44 & 33.95 \\
\hline Pod length $(\mathrm{cm})$ & 2.38 & 0.14 & 1.86 & 2.87 & 0.08 & 0.04 & 0.04 & 11.84 & 8.33 & 49.49 & 0.29 & 12.05 \\
\hline 100 seed Weight (g) & 39.20 & 2.84 & 29.07 & 59.87 & 73.23 & 61.10 & 12.13 & 21.83 & 19.94 & 83.44 & 14.68 & 37.45 \\
\hline Shelling percentage (\%) & 71.17 & 2.25 & 60.67 & 77.83 & 16.49 & 7.88 & 8.62 & 5.71 & 3.94 & 47.76 & 3.99 & 5.60 \\
\hline Dry pod yield (kg/ha) & 1237 & 215 & 800 & 2348 & 195362 & 125390 & 69972 & 35.7 & 28.6 & 64.18 & 583.3 & 47.14 \\
\hline Grain yield (kg/ha) & 898 & 156 & 529 & 1744 & 102896 & 66360 & 36536 & 35.7 & 28.7 & 64.49 & 425.3 & 47.36 \\
\hline Oil content $(\%)$ & 44.86 & 0.64 & 41.5 & 48.89 & 4.17 & 3.33 & 0.84 & 4.55 & 4.07 & 79.91 & 3.36 & 7.48 \\
\hline
\end{tabular}

Table 5. Estimates of variance components, phenotypic (PCV) and genotypic $(G C V)$ coefficient of variability, broad sense heritability $\left(h^{2}\right)$, expected genetic advance (EGA) and genetic advance as percentage of mean (GAM\%) for 16 traits of groundnut genotypes tested at Kamashi.

\begin{tabular}{|c|c|c|c|c|c|c|c|c|c|c|c|c|}
\hline Traits & Mean & SE & $\begin{array}{l}\text { Range } \\
\text { Min. }\end{array}$ & Max. & $\sigma_{p h}^{2}$ & $\sigma_{g}^{2}$ & $\sigma^{2} \mathrm{e}$ & PCV & GCV & $h^{2}{ }_{b}$ & $\begin{array}{l}\text { EGA } \\
K=5 \%\end{array}$ & $\begin{array}{l}\text { GAM } \\
k=5 \%\end{array}$ \\
\hline Days to $50 \%$ flowering (days) & 38.01 & 0.78 & 36.00 & 40.00 & 1.77 & 0.86 & 0.91 & 3.50 & 2.44 & 48.54 & 1.33 & 3.49 \\
\hline Days to maturity (days) & 129.5 & 1.22 & 124.7 & 136.0 & 13.88 & 11.62 & 2.26 & 2.88 & 2.63 & 83.74 & 6.41 & 4.96 \\
\hline Plant height $(\mathrm{cm})$ & 41.22 & 2.81 & 28.80 & 52.53 & 35.06 & 21.00 & 14.07 & 14.36 & 11.12 & 59.88 & 7.29 & 17.69 \\
\hline Primary branches per plant (no) & 6.53 & 0.60 & 4.73 & 10.40 & 1.99 & 1.35 & 0.64 & 21.60 & 17.78 & 67.74 & 1.96 & 30.08 \\
\hline Secondary branches per plant (no) & 2.17 & 0.41 & 1.33 & 3.67 & 0.43 & 0.13 & 0.30 & 30.30 & 16.90 & 31.11 & 0.42 & 19.38 \\
\hline Total Pods per plant (no) & 27.99 & 2.60 & 19.53 & 41.40 & 30.41 & 20.13 & 10.27 & 19.70 & 16.03 & 66.22 & 7.51 & 26.82 \\
\hline Pod length $(\mathrm{cm})$ & 2.63 & 0.16 & 2.17 & 3.25 & 0.08 & 0.04 & 0.04 & 10.82 & 7.85 & 52.67 & 0.31 & 11.72 \\
\hline 100 seed Weight $(\mathrm{g})$ & 42.79 & 1.81 & 32.59 & 59.73 & 45.32 & 39.94 & 5.39 & 15.73 & 14.77 & 88.12 & 12.20 & 28.51 \\
\hline Shelling percentage $(\%)$ & 74.66 & 2.19 & 65.00 & 81.00 & 18.40 & 11.14 & 7.26 & 5.75 & 4.47 & 60.54 & 5.34 & 7.15 \\
\hline Dry pod yield (kg/ha) & 2523 & 232 & 1676 & 3524 & 303034 & 222094 & 80940 & 21.82 & 18.68 & 73.29 & 829.5 & 32.88 \\
\hline Grain yield (kg/ha) & 1957 & 198 & 1128 & 2859 & 210752 & 150778 & 59974 & 23.46 & 19.85 & 71.54 & 675.3 & 34.51 \\
\hline Oil content $(\%)$ & 50.43 & 1.22 & 47.80 & 54.73 & 4.12 & 1.65 & 2.47 & 4.03 & 2.55 & 40.05 & 1.67 & 3.31 \\
\hline
\end{tabular}

Where: - Min. $=$ minimum, Max $=$ maximum, $\mathrm{k}=$ selection intensity, $\mathrm{SE}=$ standard error, $\sigma_{\mathrm{ph}}^{2}=$ phenotypic variance, $\sigma_{\mathrm{g}}^{2}=$ genotypic variance, $\sigma_{\mathrm{e}}^{2}=$ environmental variance.

\subsubsection{Heritability in Broad Sense}

Broad sense heritability $\left(\mathrm{h}_{\mathrm{b}}{ }^{2}\right)$ which is an estimate of the total contribution of the genetic variance to the total phenotypic variance ranged from $30.07 \%$ to $83.4 \%$ at Assosa and from $27.93 \%$ to $88.1 \%$ at Kamashi for late leaf spot and 100-seed weight, respectively (Tables 4 and 5). [12] generally classified heritability estimates as low for values $(<40 \%)$, medium $(40-59 \%)$, high $(60-79 \%)$ and very high above $80 \%$.

Thus, based on this classification, 100-seed weight, oil content, primary branches per plant, days to $50 \%$ flowering, grain yield per hectare, dry pod yield per hectare and plant height showed high heritability at Assosa location. At Kamashi high heritability were observed for 100 -seed weight, days to maturity, dry pod yield per hectare, grain yield per hectare, primary branches per plant, total pods per plant and shelling percentage. These indicated genetic makeup played a major role in the expression of these traits and ultimately less environmental influence.

The result in this study was in agreement with the finding of [2] who reported the existence of high heritability for days to $50 \%$ flowering, days to maturity, shelling percentage, pod yield (kg/ha) and Kernel yield (kg/ha). [4] also reported high heritability estimates for days to $50 \%$ flowering, days to maturity, number of mature pods per plant, biological yield per plant, pod yield per plant, biological yield per hectare, pod yield per hectare, harvest index, shelling percentage, kernel yield per plant, kernel yield per hectare, 100 kernel weight and oil content indicated little influence of environment on the inheritance of these characters. Hence, selections for traits with high heritability will lead to fast genetic improvement of a trait that is by increasing the frequency of favorable alleles by repeated mass selection or hybridization between selected genotypes, showing varying degree of variation for such traits.

Medium heritability also observed from this experiment for secondary branches per plant, pod length, days to maturity, shelling percentage, mature pods per plant and total pods per plant at Assosa and for plant height, pod length and days to $50 \%$ flowering at Kamashi. Early leaf spot and late leaf spot showed low heritability at both Assosa and Kamashi locations. Number of secondary branches per plant, mature pods per plant and oil content exhibited low heritability at Kamashi. This study is in agreement with [14] who reported 
low heritability for seeds per pod.

\subsubsection{Estimates of Expected Genetic Advance}

Johnson et al. (1955) classified genetic advance as a percentage of the mean (GAM $\%$ ) that, values from $0-10 \%$ as low, $10-20 \%$ as moderate and $20 \%$ and above as high. Accordingly, high heritability coupled with high genetic advance as percent of mean (GAM\%) was recorded for primary branches per plant, 100-seed weight, dry pod yield per hectare and grain yield per hectare at Assosa. At these location traits like secondary branches per plant, total pods per plant and mature pods per plant showed medium heritability with high GAM. At Kamashi primary branches per plant, total pods per plant, 100-seed weight, dry pod yield per hectare and grain yield per hectare showed high heritability coupled with high GAM. Plant height and pod length exhibited moderate heritability coupled with moderate GAM at Kamashi. The high heritability coupled with GAM observed for the above traits in this experiment attributed to additive gene effect, which can be easily improved by simple phenotypic selection. Similar findings were reported by [3] for plant height, secondary branches per plant, pod yield per plant, pod yield per hectare, and percent of disease incidence at harvest, indicated that there was lower environmental influence on the expression of these traits and governed by additive gene action and hence selection would be effective. [15] also reported high heritability coupled with high genetic advance as percent of mean for hundred kernel weight, dry pod yield, kernel yield, plant height and number of pods per plant indicating the role of additive gene in expressing these traits and revealed better scope for improvement of these traits through direct selection.

Days to maturity, shelling percentage and oil content exhibited low GAM but moderate to high heritability at both locations. However, early and late leaf spot showed high GAM but low heritability at both locations in this experiment. At Kamashi secondary branches per plant and mature pods per plant showed low heritability but moderate GAM. A low GAM and low GCV observed for those traits indicated that the characters were governed by non-additive gene action, and that selection based on these characters would be ineffective. [14] Reported low heritability and low GAM for shelling percentage and seeds per pod.

\section{Conclusions}

The lowland areas of Ethiopia have considerable potential for increased oil crop production including groundnut. In Benishangul Gumuz Region, groundnut is cultivated in various zones and woredas under rain fed condition. However, due to insufficient improved groundnut varieties found in the region the productivity was low. Knowledge on the extent and pattern of genetic variability present in a population and interrelationship among characters are essential to design breeding strategies in crop improvement. To generate such information 25 groundnut genotypes including two released varieties (Maniputer and
Roba) were tested in 5x5 triple lattice designs under rain fed condition at Asosa and Kamashi research field of Assosa Agricultural Research Center in Benishangul-Gumuz regional state, Western Ethiopia. Data were collected for 16 traits on plot base as well as plant bases and subjected to analysis of variance using SAS software proc lattice and GLM procedure for individual location and combined of the two locations The analyses of variance showed that, mean square due to genotype were highly significant for all considered traits among the tested genotype at both locations, except seeds per pod which was non-significant. These implied the presence of considerable variation among genotypes. The result also showed that high dry pod yield and grain yield per hectare were obtained from those late maturing genotypes compared to the early maturing materials, indicating the late mature genotypes provide high dry pod yield and grain yield per hectare. The PCV was higher than the GCV for all traits studied at both locations, indicating that the apparent variation was not only genetic but also was influenced by the growing environment in the expression of the traits. High GCV and PCV values were observed for number of primary branches per plant, secondary branches per plant, total pods per plant, mature pods per plant, dry pod yield per hectare, grain yield per hectare, early leaf spot and late leaf spot at Assosa. At Kamashi high GCV and PCV values were recorded for early leaf spot and late leaf spot. 100-seed weight exhibited high PCV value at Assosa, whereas, primary branches per plant, secondary branches per plant, number of mature pods per plant, dry pod yield and grain yield per hectare showed high PCV at Kamashi. Therefore, the study of GCV and PCV in tested groundnut genotypes exhibited variability for most of the characters considered. These indicated the existence of wider genetic variation in tested genotypes and implied that there is a good opportunity for the improvement of grain yield in the tested genotypes. Hence, those character can be relied upon and simple selection can be practiced for further improvement. The correlation and path coefficient analysis indicated that, dry pod yield per hectare that showed positive and strong correlation with seed yield exercised the highest positive phenotypic and genotypic direct effect at both locations and combined over the two locations. The trait will be useful for direct selection to increase grain yield. Characters like dry pod yield per hectare, primary branches, total pods per plant and 100-seed weight correlated positively and significantly and exerted positive in direct effect via dry pod yield per hectare.

Therefore, the current study revealed the presence of considerable variability for most of all traits studied and differences in the performance of the genotypes as there were statistically significant differences among genotypes. These conditions indicated that there is good opportunity to improve these characters using the tested genotypes in groundnut breeding programs. Priority should be given for dry pod yield per hectare, primary branches per plant, total pods per plant and 100-seed weight in the improvement of grain yield in groundnut breeding programs. 


\section{References}

[1] Allard. R. W. 1960. Principle of Plant Breeding. John Wiley and Son. New York.

[2] Ashish, J., Nadaf, H. L. and Gangadhara, K. 2015. Genetic variability and correlation for yield attributing traits of advanced generation recombinant inbred lines of groundnut (Arachis hypogaea L.). International Journal of Genetic Engineering and Biotechnology, 5 (2) 109 - 114.

[3] Balaraju M. and Kenchanagoudar, P. V. 2016. Genetic variability for yield and its component traits in interspecific derivatives of groundnut (Arachis hypogaea L.), Journal of Farm Science, 29 (2): 172-176.

[4] Bhargavi, G., Satyanarayana, R. V. and Narasimha, R. K. L. 2016. Genetic variability, heritability and genetic advance of yield and related traits of Spanish bunch groundnut (Arachis hypogaea L.) Agric. Sci. Digest., 36 (1): 60-62.

[5] Biru Alemu and DarajeAbera. 2014. Adaptation study of improved groundnut (Arachis hypogaea L.) varieties at Kellem Wollega Zone, Haro Sabu, Ethiopia Journal of Biology Agriculture and Healthcare 4 (23): 75-79.

[6] Burton, G. W. and Devane, E. H. 1953. Estimating heritability in tall Fescue (Festucaarundinacea) from replicated colonel materials. Agronomy Journal, 45: 487-488

[7] CSA (Central Statistical Agency). 2015. The Federal Democratic Republic of Ethiopia Central Statistical Agency Agricultural Sample Survey, Volume I Report on area and production of major Crops (Private Peasant Holdings, Meher Season), Addis Ababa, Ethiopia.

[8] Deshmukh, S. N., Basu, M. S. and Reddy, P. S. 1986. Genetic variability, character association and path coefficients and quantitative traits in Virginia bunch varieties of groundnut Indian Journal of Agricultural Science, 56: 816-821.
[9] Falconer, D. S. and Mackay T. F. C. 1996. Introduction to Quantitative Genetics. 4th ed., Longman Group Limited, Malaysia, p. 464.

[10] Fikre Hagos, Habtamu Zeleke and BulchaWoyossa. 2012. Genetic gain in yield and yield related traits of groundnut (Arachis hypogea L.) in Central Rift Valley of Ethiopia. East African Journal of Sciences 6 (2) 125-136.

[11] Johnson, H. W., Robinson, H. F. and Comstock, R. E. 1955. Genotypic and phenotypic correlations in soybean and other implications in selection, Agronomy Journal, 47: 477-483.

[12] Pramoda, H. P. S. and Gangaprasad, 2007. Biometrical basis of handling segregation population for improving productivity in onion (Allium cepa L.). Journals of Asian Horticulture, 3 (4): $278-280$

[13] Prashant, K. R., Krishna K., Arvind K., Bazil, A. S. and Chaurasia A. K. 2014. Study on the Performance of Groundnut (Arachis hypogea L.) Genotypes for Quantitative Traits in Allahabad Region, Journal of Science and Technology, 2, 564-569.

[14] Thakur, S. B., Ghimire, S. K., Pandey, M. P., Shrestha, S. M. and Mishra, B. 2011. Genetic variability, heritability and Genetic advance of pod yield component traits of groundnut (Arachis hypogaea L.), Journal of Institute of Agriculture and AnimalScience. 32: 133 - 141

[15] Thirumala, R. V., Venkanna, V., Bhadru, D. and Bharathi, D. 2014. Studies on variability, character association and path analysis on groundnut (Arachis hypogaea L.). International Journal of Pure and Applied Bioscience. 2 (2): 194-197.

[16] Vasanthi, R. P. Suneetha, N. and Sudhakar, P. 2015. Genetic variability and correlation studies for morphological, yield and yield attributes in groundnut (Arachis hypogaea L.) Agricultural Research Communication Center. 38 (1): 9-15.

[17] Zaman, M. A., Tuhina, K. M., Ullah, M. Z., Moniruzzam, M and Alam, K. H. 2011. Genetic variability and path analysis of groundnut. The Agriculturist. 9: 29-36. 